\title{
Sources of Information for Agricultural Students on Online Meeting Tools during Covid-19 Lock Down
}

\author{
M. Chenna Madhava ${ }^{1 *}$, T. Lakshmi ${ }^{1}$, B. Ramana Murthy ${ }^{2}$, \\ S. Sravani ${ }^{1}$, V. Karthiga ${ }^{1}$, Amanda Baby ${ }^{1}$ and A. Nikhitha ${ }^{1}$ \\ ${ }^{1}$ Department of Agricultural Extension, S.V. Agricultural College, Tirupati, ANGRAU \\ ${ }^{2}$ Department of Statistics and Computer Applications, S. V. Agricultural College, Tirupathi, \\ ANGRAU, India \\ *Corresponding author
}

\section{Keywords}

COVID-19, Lock down, Institutional Sources, Social Media, WhatsApp

Article Info

Accepted:

22 June 2020

Available Online:

10 July 2020

\section{A B S T R A C T}

The study was conducted to know the sources of information for agricultural students on online meeting Apps during COVID-19 lock down with a sample size of 150 respondents (i.e., Agricultural students studying in Agricultural Higher Education Institutions across A. P, Telangana, Karnataka, Tamil Nadu, Kerala). In this study $68 \%$ of respondents revealed that Teaching staff and officials of Agricultural Higher Education Institutions (Institutional Sources) are the major contributors in creating awareness about online meeting Apps among Institutional, Non Institutional and Mass Media Channels. $88.7 \%$ of the respondents opined that Social Media is major contributor among Print, Electronic, Social Media channels and $68.7 \%$ of respondents revealed that WhatsApp have played crucial role among Social Media Platforms in awareness creation about virtual meeting Apps. This study also revealed that, Age and Level of education/type of degree are the major influencing factors in a decision to choose a particular meeting App for their online classes.

\section{Introduction}

It is a well known fact that COVID-19 had shown staggering impact on global education system. Worldwide there are more than 1.2 billion learners in 186 countries are out of class room due to the pandemic (source: UNESCO).
As the corona virus pandemic started affecting India, all the colleges and schools along with Agricultural higher education institutions closed physically due to pandemic-led lock down. There are as many as 1.65 lakh students are pursuing various Undergraduate, Postgraduate and Doctoral programmes in various Agricultural 
institutions

https://education.icar.gov.in/) across the country were impacted due to pandemic and their academic activities were significantly disrupted.

Based on UGC Guidelines for the Universities in view of COVID-19 pandemic and in consultation with academic experts and administrators of agricultural universities, the ICAR has taken several immediate measures to ensure continuity in teaching- learning process. ICAR along with NAHEP, NARES responded well to the situation and started taking advantage of technology to bring classes online via various online meeting apps.

But, the challenge is to find the best online conferencing solution for specific e-Learning needs, especially when there are so many options available and also many students are unaware of online meeting apps beforeCOVID-19 lock down. Keeping all these things in mind this study was conducted to know what are the major informational sources that has been contributed significantly to create awareness about online meeting apps among the agricultural higher education students during lock down period and also to know the role of demographics in choosing particular online meeting app.

\section{Materials and Methods}

The data were collected during June, 2020 on a structured survey schedule administered as an online survey using Google forms and data were collected purposively from A.P, Telangana, Tamil Nadu and Kerala states. A total of 150 respondents have been selected on simple random basis from various Agricultural Higher Education Institutions studying in these 5 states. Care has been taken to eliminate multiple responses during the online survey and all the respondents included in the sample are unaware of online meeting
Apps before pandemic-led lockdown.

The data collected was categorized and tabulated according to demographics, type of online meeting App used, sources of information in awareness creation.

The Pearson chi square test $\left(\chi^{2}\right)$ was performed to know the significance of association between the demographics of the respondents and type of online App used, sources of information in awareness creation. The computation was done by using SPSS statistical program.

\section{Results and Discussion}

\section{Distribution of respondents according to demographics}

Results pertaining to distribution of respondents according to demographic characteristics is presented in table 1. The findings shows that highest number of respondents belongs to the 21-25 years age group (70.7\%) followed by $16-20$ years age group $(25.3 \%)$ and $26-30$ years $(2.7 \%)$ and least number of respondents are in $>30$ years age group $(1.3 \%)$. This might be due to the most of the students studying in Agricultural Higher Educational Institutions are in between 21-25 years, 16-20 years and there are few students belongs to $>30$ years are studying in these institutions. Then $58.7 \%$ of the respondents are females and $41.3 \%$ of the respondents are males.

The highest number of respondents are pursuing Under graduation $(56.7 \%$ ) followed by Post graduation (40\%) and $\mathrm{PhD}$ (3.3\%).These results are in the order of (i.e., Under graduation, Post graduation, $\mathrm{PhD}$ respectively)total number of students pursuing these 3 degree programmes in various Agricultural Higher Education Institutions. 
Distribution of respondents according to type of online meeting App used

Table 2 clearly shows that $52.7 \%$ of the students are using Zoom mobile application for their online classes followed by Google Meet (38.7\%), Webex (4.6\%) and Others $(4.0 \%)$.

Distribution of respondents according to sources of information in awareness creation

From the Table 3, highest number of respondents $(68 \%)$ opined that Teaching staff and officials of Agricultural Higher Education
Institutions (Institutional/Formal sources) are major sources of information in creating awareness about online meeting Apps followed by Mass Media Channels (17.3\%) and Non Institutional/Informal sources i.e., Friends, Neighbours, Relatives, Family members (14.7\%). Past research on sources of information suggesting that Mass Media channels are actively involved at awareness stage of any new technology. But in contrast the results are showing that Institutional sources have played crucial role in creating awareness about online meeting Apps. The reason might be awareness stage was coincided with trial and adoption stages due to an abnormal situation (Pandemic).

Table.1 Distribution of respondents according to demographics ( $\mathrm{N}=150)$

\begin{tabular}{|l|c|c|}
\hline Variables & Frequency $(\mathbf{N})$ & Percentage $(\%)$ \\
\hline AGE & & \\
16-20 years & 38 & 25.3 \\
21-25 years & 106 & 70.7 \\
26-30 years & 4 & 2.7 \\
> 30 years & 2 & 1.3 \\
& & \\
GENDER & 88 & 58.7 \\
Female & 62 & 41.3 \\
Male & & \\
EDUCATION & $\mathbf{8 5}$ & $\mathbf{5 6 . 7}$ \\
Under graduation & 60 & $\mathbf{4 0}$ \\
Post graduation & $\mathbf{5}$ & $\mathbf{3 . 3}$ \\
PhD & Source: Online Survey 2020 \\
\hline
\end{tabular}

Table.2 Distribution of respondents according to type of online meeting app used ( $\mathrm{N}=150)$

\begin{tabular}{|l|l|l|}
\hline Variable & Frequency (N) & Percentage (\%) \\
\hline Online Meeting App & & \\
\hline Zoom & $\mathbf{7 9}$ & $\mathbf{5 2 . 7}$ \\
Google Meet & $\mathbf{5 8}$ & $\mathbf{3 8 . 7}$ \\
Webex & 7 & $\mathbf{4 . 6}$ \\
Others & $\mathbf{6}$ & $\mathbf{4 . 0}$ \\
\hline
\end{tabular}

Source: Online Survey 2020 
Table.3 Distribution of respondents according to sources of information in awareness creation $(\mathrm{N}=150)$

\begin{tabular}{|l|c|c|}
\hline Variables & Frequency(n) & Percentage (\%) \\
\hline $\begin{array}{c}\text { Major Sources of Information } \\
\text { Teaching staff and officials of } \\
\text { Agricultural Higher Education Institutes }\end{array}$ & 102 & 68.0 \\
Friends, Neighbors, Relatives, & 22 & \\
Family members & & 14.7 \\
Mass Media Channels (Print, & 26 & \\
Electronic, Social Media) & & 17.3 \\
& & \\
Type of Mass Media Channel & 17 & \\
\hline Electronic Media & 0 & 11.3 \\
Print Media & 133 & 0 \\
Social Media & & 88.7 \\
& 103 & \\
Type of Social Media Platform & 21 & 68.7 \\
\hline WhatsApp & 12 & 14.0 \\
You Tube & 8 & 8.0 \\
Instagram & 6 & 5.3 \\
Face Book & & 4.0 \\
Others & & \\
\hline
\end{tabular}

Source: Online Survey 2020

Table.4 Pearson Chi - square $\left(\chi^{2}\right)$ values for demographics versus type of online meeting app used, sources of information in awareness creation $(\mathrm{N}=150)$

\begin{tabular}{|c|c|c|c|c|}
\hline & & AGE & GENDER & EDUCATION \\
\hline \multirow{3}{*}{$\begin{array}{l}\text { Online meeting app } \\
\text { used }\end{array}$} & $\chi^{2}$ VALUE & 20.001 & 7.530 & 27.546 \\
\hline & $P$-VALUE & $0.018^{*}$ & 0.06 & $0.00 * *$ \\
\hline & SIGNIFICANCE & S & NS & $S$ \\
\hline \multirow{3}{*}{$\begin{array}{l}\text { Major sources of } \\
\text { information }\end{array}$} & $\chi^{2}$ VALUE & 5.978 & 3.571 & 4.954 \\
\hline & $P$-VALUE & 0.426 & 0.168 & 0.292 \\
\hline & SIGNIFICANCE & NS & NS & NS \\
\hline \multirow{3}{*}{$\begin{array}{l}\text { Type of mass media } \\
\text { channel }\end{array}$} & $\chi^{2}$ VALUE & 9.471 & 1.124 & 4.408 \\
\hline & $P$-VALUE & $0.024^{*}$ & 0.289 & 0.110 \\
\hline & SIGNIFICANCE & $\mathrm{S}$ & NS & NS \\
\hline \multirow{3}{*}{$\begin{array}{l}\text { Type of social } \\
\text { mediaplatform }\end{array}$} & $\chi^{2}$ VALUE & 8.648 & 3.721 & 6.885 \\
\hline & $P$-VALUE & 0.733 & 0.445 & 0.549 \\
\hline & SIGNIFICANCE & NS & NS & NS \\
\hline
\end{tabular}

NOTE: " and ** indicates significance at $5 \%$ and $1 \%$ level of significance respectively.

NS= Non significant,$S=$ Significant 
$88.7 \%$ of the respondents opined that Social Media have contributed in awareness creation followed by Electronic Media (11.3\%) among Mass Media Channels. Significantly highest per cent of Social Media might be due to it's wide range of accessibility. But one important finding in this study is that none of the respondents $(0 \%)$ have reported the role of Print Media in awareness creation. This might be due to the very low level of accessibility to Print Media channels like news papers during pandemic-led lock down.

Highest number of respondents (68.7\%) opined that WhatsApp have played important role in awareness creation among various Social Media Platforms followed by You Tube (14\%), Instagram (8\%), Face Book $(5.3 \%)$ and Others (4\%). The reason might be due to WhatsApp will allow the people in intense inter personal communication than any other Social Media Platform and inter personal channels will in turn act as a reliable source of information.

Pearson chi square $\left(\chi^{2}\right)$ test for demographics versus type of online meeting App used, sources of information in awareness creation

Pearson chi square test results in Table 4 showing that there is a significant relationship between the Age and type of online meeting App used $\chi^{2}=20.001, p=0.018, p<0.05$.

It is also showing that there is there is a significant association between the level of education of respondent and type of online meeting App used by him $\chi^{2}=27.546, p=$ $0.00, \mathrm{p}<0.01$. From here it is evident that level of education/type of degree will play a role in decision to choose a particular meeting App for their online classes.
There is a significant association between the Age of the respondent and type of Mass Media Channel $\chi^{2}=9.471, \mathrm{p}=0.024, \mathrm{p}<0.05$.

In conclusion, it was discovered that Institutional Sources (Teaching staff and officials of Agricultural Higher Education Institutions) have played a crucial and very important role in creating awareness about virtual meeting tools and succeeding in preparing the students for online classes for teaching-learning continuity.

It was also found that Age and level of education have played major role in choosing a particular online meeting App for their virtual classes.

The type of Mass Media Channel involved in creating awareness about online meeting Apps vary with the Age.

\section{References}

Thammi-Raju, D., Ramesh, P., Krishna, P., Soam, SK., Sriniasrao, Ch., Agarwal, RC. 2020. RE-imaging Higher Agricultural Education in India on the Face of Challenge from COVID-19 Pandemic - Strategies for Adopting to the New Normal. ICAR Policy Paper, Indian Council of Agricultural Research (ICAR), New Delhi, p14.

Milan Slavic (2004). Changes in information systems in Czech agriculture, The Journal of agricultural education and extension 10 (4), 193-202, 2004.

Lou E. Riesenberg (1989), Farmers Preferences for Methods of Receiving Information on New or Innovative Farming Practices, Fall 1989. 
How to cite this article:

Chenna Madhava, M., T. Lakshmi, B. Ramana Murthy, S. Sravani, V. Karthiga, Amanda Baby and Nikhitha, A. 2020. Sources of Information for Agricultural Students on Online Meeting Tools during Covid-19 Lock Down. Int.J.Curr.Microbiol.App.Sci. 9(07): 3470-3475. doi: https://doi.org/10.20546/ijcmas.2020.907.405 